\title{
Tadeusz Pieronek
}

\section{Normy postępowania w sprawach małżeńskich wydane przez Stolicę Apostolską dla diecezji Stanów Zjednoczonych}

Prawo Kanoniczne : kwartalnik prawno-historyczny 16/1-2, 177-204

1973

Artykuł został zdigitalizowany i opracowany do udostępnienia w internecie przez Muzeum Historii Polski w ramach prac podejmowanych na rzecz zapewnienia otwartego, powszechnego i trwałego dostępu do polskiego dorobku naukowego i kulturalnego. Artykuł jest umieszczony w kolekcji cyfrowej bazhum.muzhp.pl, gromadzącej zawartość polskich czasopism humanistycznych i społecznych.

Tekst jest udostępniony do wykorzystania w ramach dozwolonego użytku. 
KS. TADEUSZ PIERONEK

\section{NORMY POSTEPOWANIA W SPRAWACH MAEŻENSKICH WYDANE PRZEZ STOLICE APOSTOLSKA DLA DIECEZJI STANOW ZJEDNOCZONYCH}

Treść: Wstęp. I. Jak doszło do wydania Norm. II. Charakter i cel Norm. III. Zmiany $w$ dotychczasowych przepisach procesu malżeńskiego wprowadzone przez Normy. Uwagi końcowe.

\section{Wstęp}

Normy postępowania w sprawach małżeńskich, wydane przez Stolicę Apostolską dla diecezji Stanów Zjednoczonych Ameryki Północnej, mają przede wszystkim znaczenie lokalne, na terenie dla którego zostały wydane. Moment jednak w jakim weszły one w życie, decyduje o tym, że powinny się one stać przedmiotem zainteresowania kanonistyki w całym Kościele. Jest to moment, w którym krystalizują się idee reformy prawa kanonicznego w ogóle, a wśród nich i przepisów postępowania w sprawach małżeńskich. Każda zmiana dokonana $w$ tej dziedzinie przez Stolice Apostolską, chociażby o charakterze lokalnym i tytułem próby, rzutuje na zbliżającą się reformę norm ustawodawstwa powszechnego w tej dziedzinie.

\section{Jak doszlo do wydania Norm}

W odpowiedzi na liczne głosy krytyki pod adresem kodeksowego systemu procesu małżeńskiego, zgłoszone w propozycjach soborowych przesłanych do Rzymu ${ }^{1}$, Sobór Watykański II zajął się kwestią jego reformy. Soborowa Komisja De disciplina sacramentorum przygotowała projekt dekretu De matrimonii sacramento, w którym znalazł się również specjalny schemat De processu matrimoniali ${ }^{2}$. Cały projekt jednak, na zlecenie Soborowej Komisji Koordynacyjnej został później zredukowany do prostego votum, które $z$ kolei zostało zepchnięte na margines obrad soborowych i nie weszło do żadnego soborowego dokumentu.

Votum to, w części dotyczącej procesu małżeńskiego postanawiało: „Bieg spraw małżeńskich winien być szybszy. Dla zapobieżenia zaś nadużyciom, dyscyplinę procesu małżeńskiego należy zabezpie-

1 Acta et documenta Concilio Oecumenico Vaticano II apparando, Series I (Antipreparatoria), Typis Polyglottis Vaticanis 1961, Appendix vol. II, pars II, s. 580-593.

2 Il Concilio Vaticano II, Il primo periodo 1962-1963, opr. G. C a p r le, wyd. „La Civiltà Cattolica”, Roma 1968, vol. II, s. 332-333; vol. IV (Roma 1965), s. 491-493. 
czyć odpowiednimi środkami. Trzeba ustalić nową dyscyplinę tych procesów, w której przede wszystkim zaradzi się i zabezpieczy tak przygotowanie $i$ wybór zdatnych sędziów, którym znajomość rzeczy i ludzi nie jest obca, jak i wykonywanie bezpłatnej funkcji adwokackiej, o ile to możliwe. Wypadki, które w obecnej dyscyplinie kanonicznej wyjęte są ze zwykłego procesu, należy w sposób definitywny poszerzyć. $W$ całym zaś stanowieniu praw niech przebija duch miłości i łagodności Chrystusowej, który zawsze stanowi złotą i niezmienną regułę Kościoła i winien przepajać prawa i procesy" 3 .

Sformulowania te byly wprawdzie przedmiotem soborowej dyskusji na 126 i 127 kongregacji generalnej, ale byly to już dwa ostatnie dni dyskusji podczas trzeciej sesji soborowej, tekst projektu budził wiele zastrzeżeń, zwłaszcza $\mathrm{w}$ kwestiach związanych $z$ problemem małżeństw mieszanych i dlatego dyskusję przerwano, w związku z czym i cała reforma procesu małżeńskiego, nie nakreślona nawet oficjalnie przez Sobór, przeszła w ręce Papieskiej Komisji Rewizji Kodeksu Prawa Kanonicznego 4. Komisja w toku swych prac poświęciła tej sprawie posiedzenia $\mathrm{w}$ maju 1969 r. $^{5}$ i w marcu 1970 r. ${ }^{6}$.

O reformie procesu małżeńskiego pomyślano też $w$ związku $z$ pracą nad ustaleniem zasad rządzących odnową Kodeksu Prawa Kanonicznego, której wyniki przedstawiono do zatwierdzenia I Synodowi Biskupów w $1967 \mathrm{r}^{7}{ }^{7}$, padł też $\mathrm{w}$ tej sprawie nie jeden głos podczas debat synodalnych 8 .

$\mathrm{Na}$ drodze przygotowań do synodu powstało szereg propozycji, sporządzonych bądź oficjalnie przez zaproszone do współpracy Konferencje Episkopatu ", bądź przez zrzeszone grupy kanonistów ${ }^{10}$, bądź wreszcie przez kanonistów jako osoby prywatne ${ }^{11}$.

3 Relatio super Schema Voti de matrimonii sacramento cum textu emendato, Typis Polyglottis Vaticanis 1964, s. 13.

4 Ca p rile G., Il Concilio Vaticano II, vol. IV, s. 498-499.

5 Communicationes, 1 (1969) 52.

- Communicationes, 1 (1970) 80.

- Communicationes, 2 (1969) 79-83.

8 Caprile G., Il sinodo dei vescovi, Prima assemblea generale (29 settembre - 29 ottobre 1967), Roma 1967, s. 94-133.

${ }^{9}$ Listem z dnia 25 i 29 marca $1967 \mathrm{r}$. Sekretariat Generalny Synodu Biskupów przesłał Konferencjom Episkopatu materiał, który miał być przedmiotem dyskusji na synodzie (C a p rile G., Il sinodo dei vescovi, s. 38). Owocem prac nad tym materiałem były $\mathrm{m}$. i. wnioski Konferencji Biskupich dotyczące rewizji, prawa procesowego. W Polsce utworzono w czerwcu 1967 r. Podkomisję Rewizji Kodeksu Prawa Kanonicznego, do której powołano kanonistów z calego kraju. Podkomisja była podzielona na Sekcje. Sekcji, której zadaniem było opracowanie wniosków dotyczących księgi IV Kodeksu De processibus, przewodniczył ks. bp J. Z a rę ba. Wyniki prac Podkomisji miały być dostarczone do 
Pierwszego źródła Norm należy szukać wśród tych ostatnich, prywatnych propozycji. Jakkolwiek pierwsza ich wersja została opublikowana dopiero w roku 1968 pod egidą Canon Law Society of America w czasopiśmie Newsletter, nie ulega jednak wątpliwości, że ich autorem był Stefan J. K el le he r, ówczesny oficjał Trybunału Metropolitalnego w Nowym Jorku, który poprzez Canon Law Society of America zakomunikował je już 25 września 1965 r. wszystkim jej czlonkom, dając swym propozycjom tytuł Rules for the Processing of Marriage Cases in Formal Trial ${ }^{12}$.

W styczniu 1969 r. St. J. Kelleher opublikował nowy, zreformowany tekst Norm 13, bardzo zbliżony do tego, który Stolica Apostolska zatwierdziła dnia 28 kwietnia $1970 \mathrm{r}$. dla diecezji Stanów Zjednoczonych Ameryki Północnej, na prośbę przedstawioną przez tamtejszą Konferencję Episkopatu.

\section{Charakter i cel Norm}

Normy zostały wydane przez Radę dla Międzynarodowych Spraw Kościelnych, za specjalną zgodą pap. Pawła VI, na okres trzech lat i tytułem próby, a weszly w życie $z$ dniem 1 lipca $1970 \mathrm{r}$. Oryginał Norm jest w języku angielskim i nie został opublikowany w Acta Apostolicae Sedis 14. Przewodniczący Konferencji Episkopatu Stanów Zjednoczonych ma obowiązek co roku składać szczegółowe sprawozdanie ze spraw małżeńskich prowadzonych w amerykańskich trybunałach kościelnych. Sprawozdanie to należy przesłac Najwyższemu Trybunałowi Sygnatury Apostolskiej. Normy uchylają przepisy obowiązującego prawa powszechnego, $z$ zastrzeżeniem jednak, by całego procesu poza tym nie ograniczać do wspomnianych Norm, lecz zachować pozostałe i nienaruszone przez Normy przepisy prawa kanonicznego, zawarte głównie w Kodeksie Prawa Kanonicznego, jego autentycznej inter-

Rzymu przez Przewodniczącego Komisji Rewizji Kodeksu Prawa Kanonicznego przy Konferencji Episkopatu Polski, ks. bpa Piotra Kałwę.

${ }_{10} \mathrm{~Np}$. przez Konferencje oficjałów niemieckich (por. Entschliessungen der Deutschen Offizialenkonferenz 1966 zur Reform des Eheprozessrechts, W: Archiv für Katholisches Kirchenrecht, 136 (1967) 40-45, oraz przez Canon Law Society of America na 27 rocznym zebraniu w Chicago, Illinois, w październiku $1965 \mathrm{r}$. (por. The Renewal of Canon Law, W: The Jurist, 26 (1966) 165-166).

11 Bliższe dane zob. G or don J., De nimia processuum matrimonialium duratione. Factum - Causae - Remedia, W: Periodica de re morali canonica liturgica, 2-3 (1969) 562-594, oraz 4 (1969) 641-735.

12 G ordon I., De nimia processuum matr. duratione, W: Periodica de re morali canonica liturgica, 2-3 (1969) 495, nota n. 12e).

$13 \mathrm{Ke} 11 \mathrm{e}$ her St. J., A Suggested Method of Procedure in the Recognitio of the Fourth Book of the Code, W: The Jurist, 29 (1969) 78-84.

14 Tekst opublikowal M c M a nus F. R., Procedural Norms for Matrimonial Cases, W: The Jurist, 30 (1970) 363-368. 
pretacji i Instrukcji Kongregacji Sakramentów z 15 sierpnia 1936 r. Provida Mater 15.

Jako cel Norm reskrypt Stolicy Apostolskiej wymienia „przyspieszenie biegu spraw o orzeczenie nieważności małżeństwa", a ich wydanie dla Stanów Zjednoczonych uzasadnia "racją szczególnych potrzeb tego terytorium". Określenie „experimenti causa" zawarte $w$ reskrypcie wskazuje jeszcze jeden powód, mianowicie chęć zdobycia doświadczenia, czy wprowadzone zmiany istotnie pozwolą na przyspieszenie biegu spraw małżeńskich ${ }^{16}$.

\section{Zmiany $w$ dotychezasowych przepisach procesu małżeńskiego wprowadzone przez Normy}

Norma 1. Trybunal diecezjalny będzie się skladal $z$ sędziów, obrońcy węzła, rzecznika sprawiedliwości i notariuszy, a wszyscy będa wyznaczeni na urzędy przez ordynariusza. Sędziowie, obrońcy węzta $i$ rzecznik sprawiedliwości maja być kaplanami; wszyscy jednak winni posiadać przymioty wymagane przez prawo.

Norma 1 jak widać jest powtórzeniem obowiązujących przepisów kan. 1574, § 1, 1585, § 1-2 oraz 1589, § 1 i art. 14, § 2 i 4, art. 15, $\$ 1$. art. 16 i 17 Instrukcji Provida.

Norma ta jest równoznaczna $z$ odrzuceniem przez Stolicę Apostolską propozycji, według której w skład trybunału lokalnego miał wchodzić „sędzia, obrońca węzła, adwokat i notariusz", przy czym zaznaczano, że „urzędy te mogą być sprawowane przez osoby świeckie, duchownych lub zakonników. Jedynym wymaganiem do urzędu jest to, by osoby te byly katolikami i były kompetentne. Ze słusznych przyczyn adwokaci i notariusze nie będący katolikam: mogą być dopuszczeni" 17 .

Warto zwrócić uwagę na fakt, że Normy - o czym szerzej za chwilę - przypisują w procesie małżeńskim dużą rolę adwokatom, nic więc dziwnego, że logicznym następstwem tej roli określonej $w$ Normach wydawal się postulat zaliczenia adwokata $w$ poczet trybunału 18.

Norma 1 nie wymaga kapłaństwa jako warunku pełnienia funkcji notariusza. Wprawdzie i w Kodeksie Prawa Kanonicznego nie

15 Reksrypt Stolicy Apostolskiej, którego tekst podaję w dodatku, mowi ogólnie o obowiązującym prawie. Zwrócenie uwagi na Instrukcję Provida i autentyczną interpretację Kodeksu ma charakter przykładowy.

16 Reskrypt nie wspomina w ogóle o stanie sądownictwa kościelnego w USA, który, jak się wydaje, jest jedną z zasadniczych „racji szczególnych" (por. Fis ke E. B., Catholic Marriage Courts Facing Re-evaluation, w The New York Times z dnia 22 grudnia 1970 r., s. 1 i 42).

$17 \mathrm{~K}$ e 11 e h e r St. J., dz. cyt., s. 79.

$18 \mathrm{~L}$ efe bvre C., De procedura in causis matrimonialibus concessa Conferentiae Episcopali USA, W: Periodica de re morali canonica liturgica, 4 (1970) 566, nota n. 17. 
był to warunek bezwzględny, ustaliła sie jednak praktyka, że świeckich na to stanowisko nie mianowano, a powierzanie go siostrom zakonnym 19 nie bylo zbyt powszechne. Na mocy przepisu normy 1 notariuszem trybunału kościelnego w Stanach Zjednoczonych może być także i kobieta.

Norma 2. Ordynariusz mianuje przewodniczacego, który pokieruje praca trybunatu i wyznaczy sędziów i obronców węzła do poszczególnych wypadków.

Norma ta zawiera jedynie nieco odmienną terminologię. Jak wynika $z$ dalszych sformułowań, Normy $w$ ogóle nie posługują się terminem oficjał, a używają w jego miejsce określenia przewodniczący czy sędzia główny (a chief judge). Określenie jest zaczerpnięte $z$ cywilnego ustawodawstwa angielskiego ${ }^{20}$, ale nie jest też całkowicie obce kanonistyce. Zadania przewodniczącego trybunału kolegialnego nie są wprawdzie w Kodeksie wystarczająco określone, ale już Instrukcja Provida dość jasno je ustala, co zdaniem wielu autorów można odnieść do wszelkich procesów, w których występuje trybunał kolegialny ${ }^{21}$.

Norma 3. Do każdego wypadku musi być ustanowiony trybunat kolegialny. Konferencja Biskupów, zgodnie z uprawnieniem, o które należy się postarać u Stolicy Świętej, może zezwolić właściwemu trybunałowi kościelnemu na uchylenie tej normy na oznaczony okres czasu tak, by sprawa mogla być zatatwiona przez pojedynczego sędziego.

Warunki sa następujace: 1) istnienie poważnej racji za przyznaniem uchylenia $i$ 2) nie wyrażenie formalnego sprzeciwu, przed wydaniem ostatecznego wyroku, ani przez sędziego, ani przez obrońcę węzla, rzecznika sprawiedliwości, czy któraś ze stron.

Diecezjalne trybunały kolegialne są $w$ Kościele, jak wiadomo, instytucją stosunkowo młodą. Po raz pierwszy wprowadził je pap. Grzegorz XVI (1831-1846) w 1831 r. dla państwa kościelnego. Instytucję tę naśladowały diecezje ${ }^{22}$, ale regułą prawa powszechnego $\mathrm{w}$ stosunku do określonych wypadków, $m$. i. do spraw małżeńskich stały się one dopiero w Kodeksie Prawa Kanonicznego (kan. 1576, § 1-3), przy czym chodziło głównie o to, by rozstrzyganiu

${ }^{19} \mathrm{G}$ ordon I., De processibus. Annotationes in $l$. IV Codicis Iuris Canonici, Romae 1965/66, s. 168.

${ }^{20}$ L e fe bvre C., dz. cyt., s. 567.

21 R o berti Fr., De processibus, In Civitate Vaticana 1956, t. I, wyd. 4, s. 267-268; C a p pell o F., Summa Iuris Canonici - De processibus, delictis et poenis, Romae 1955 , wyd. 4 , t. III, s. 86-88.

22 Wernz F. - Vidal P., Ius Canonicum - De processibus, Romae 1927, t. VI, s. 81-82; Goyeneche S., De processibus, Messanae 1958, (pro manuscripto), t. I, s. $73-74$. 
spraw małżeńskich zagwarantować możliwie najdalej idącą bezstronność. Do dziś dnia kanonistyka nie potrafiła definitywnie rozstrzygnąć jaki trybunał, jednoosobowy czy kolegialny, lepiej służy wymiarowi sprawiedliwości, zwłaszcza jeśli wziąć pod uwagę całość zagadnień które się z tym łączą, jak konieczność nie tylko bezstronności, ale także szybkiego działania, zapewnienia trybunałom wystarczającej ilości kwalifikowanych osób i wielu innych związanych $z$ tym spraw ${ }^{23}$.

Szybszym działaniem sędzia jednoosobowy niewątpliwie przewyższa trybunał kolegialny, często też utworzenie trybunału kolegialnego jest niemożliwe, ze względu na brak odpowiedniej ilości kwalifikowanych sędziów.

Norma 3, obok zasady ogólnej, wymagającej do rozstrzygania spraw małżeńskich trybunału kolegialnego, dopuszcza także mo żliwość tworzenia trybunału jednoosobowego, na wzór federalnych i stanowych trybunałów amerykańskich pierwszej instancji 24. Możliwość taka jest jednak obwarowana szeregiem zastrzeżeń ogólnych:

$1^{\circ}$ - Sama norma wprost nie udziela Konferencji Episkopatu uprawnień do zezwolenia na rozstrzyganie spraw małżeńskich przez trybunał jednoosobowy, ale o takie uprawnienie trzeba się dopiero postarać u Stolicy Apostolskiej.

Dziwny to przepis i nie wiadomo na jakich oparty przesłankach. Gdyby Stolica Apostolska miała udzielać takich uprawnień do każdego wypadku, nie byłoby potrzebne pośrednictwo Konferencji Episkopatu, jeśli zaś Konferencja Episkopatu może w tej mierze otrzymać uprawnienia o charakterze trwałym, to dlaczego nie udzielają ich same Normy, skoro sam fakt umieszczenia w Normach tej możliwości świadczy o tym, że Konferencja Episkopatu Stanów Zjednoczonych Ameryki Pólnocnej o nie prosiła?

Jedynym wytłumaczeniem takiego stanowiska Stolicy Apostolskiej wydaje się być chęć posiadania przekonywującej dokumentacji faktycznej, że potrzeba powołania trybunałów jednoosobowych naprawdę istnieje.

$2^{\circ}$ - O zezwolenie na powolanie trybunału jednoosobowego winien się zwrócić ordynariusz m. do Konferencji Episkopatu, która zaopatrzona $\mathrm{w}$ odpowiednie uprawnienia przez Stolicę Apostolską, może, ale nie musi na to zezwolić.

Nie wydaje się by mógł o to prosić przewodniczący trybunału, gdyż Kodeks w kan. 1576, § 2, zastrzega ordynariuszowi $\mathrm{m}$. prawo

23 Gordon I., De processibus, s. 154; Regatill o E., Institiones Iuris Canonici, Santander 1961, wyd. 6, t. II, s. 529; P i e r o n e k T., Normy ogólne kanonicznego procesu sq̨dowego, Cz. I, Warszawa 1970, s. 114 -115 .

${ }^{24}$ Le f e b v re C., dz. cyt., s. 569. 
powierzenia większej liczbie sẹdziów niż przepisana w $\S 1$ tegoż kanonu innych spraw, zwłaszcza trudniejszych, ze względu na towarzyszące im okoliczności. Jeśli więc tylko ordynariusz $\mathrm{m}$. może decydować o tym czy i jakie sprawy można powierzyć do rozstrzygnięcia większej liczbie sędziów, to tym bardziej decyduje o tym czy i jaką sprawę, można przekazać do osądzenia trybunalowi jednoosobowemu.

$3^{\circ}$ - Pozwolenie może być udzielone tylko konkretnemu trybunałowi, wyikluczone jest więc zezwolenie ogólne.

$4^{\circ}$ - Zezwolenie można otrzymać tylko na oznaczony okres czasu. Obok zastrzeżen ogólnych, Normy wymieniają jeszcze dwa warunki, które muszą zaistnieć, by jakaś sprawa mogła być rozstrzygana przez pojedynczego sędziego:

$1^{\circ}-\mathrm{Za}$ uchyleniem reguły ogólnej musi przemawiać poważna racja. Taka poważną racją może być chyba przede wszystkim chwilowy brak odpowiedniej ilości sędziów w diecezji, przy równoczesnej niemożliwości powołania nowych.

$2^{\circ}$ - Sam zainteresowany trybunał $\mathrm{i}$ strony procesowe musza się wobec uchylenia zachować przynajmniej biernie, gdyż „nie wyrażenie formalnego sprzeciwu, przed wydaniem ostatecznego wyroku ani przez sędziego, ani przez obrońcę węzła, rzecznika sprawiedliwości czy którąś ze stron" jest warunkiem jego udzielenia i możliwości funkcjonowania trybunału jednoosbowego.

Może zatem zaistnieć taka sytuacja, że trybunal jednoosobowy przyjmie i poprowadzi sprawe, a na skutek formalnego sprzeciwu będzie się musiał przekształcić, np. jeszcze przed zamknięciem postępowania dowodowego, $w$ trybunal kolegialny. W jaki sposób ordynariusz $\mathrm{w}$ tym wypadku postara się o odpowiednią ilość sędziów, tego Normy nie przewidują.

Norma 4. Jeśli obydwie strony pragna orzeczenia nieważności, jeden adwokat może reprezentować obydwie. Jeśli strona nie zdecydowala inaczej, adwokat pierwszej instancji winien być takize adwokatem drugiej instancji. Adwokaci reprezentujacy strony winni być zatwierdzeni do pracy $w$ sprawach matżeńskich, przez ordynariusza lub jego delegata.

Trzy kwestie poruszone w normie 4 zasługują na uwagę.

1. Według norm prawa kodeksowego nawet jedna i ta sama osoba może mieć w trybunale kilku adwokatów (kan. 1656, § 3). Przyjęło się jednak, chociaż prawo o tym milczy, że w procesie małżeńskim każda ze stron wybierała osobno dla siebie adwokata lub adwokatów, nawet $\mathrm{w}$ wypadku, gdy obydwie strony dążyły do orzeczenia nieważności ich związku małżeńskiego.

Norma 4, zezwalająca na to, by jeden adwokat bronił obydwu stron pragnących orzeczenia nieważności małżeństwa, wymaga od- 
miennej niż dotychczas interpretacji kanonu 1656 , $\$ 4$, który stanowił, że „obydwie funkcje, pełnomocnika i adwokata, także w tej samej sprawie i dla tego samego klienta, może wykonywać ta sama osoba". Wydaje się, że adwokat broniący równocześnie obydwu stron, nie może być równocześnie pełnomocnikiem jednej ze stron, bo mogłoby to stać w sprzeczności $z$ interesem drugiej strony, móglby natomiast być zarówno adwokatem, jak i pełnomocnikiem obydwu stron.

2. Według prawa kodeksowego funkcja adwokata wygasa $\mathrm{z}$ chwilą zakończenia instancji, stąd też do obrony w drugiej instancji potrzebuje on formalnego potwierdzenia przez stronę, która go wybrała 25. Norma 4 odwraca tę zasade.. Adwokat pierwszej instancji winien być także adwokatem drugiej, chyba że strona zdecydowała inaczej.

$\mathrm{Na}$ pytanie, czy mandat dany adwokatowi pierwszej instancji dotyczy również trzeciej instancji, trzeba odpowiedzieć negatywnie. Trzecią instancją dla trybunałów diecezjalnych jest bowiem Rota Rzymska, w niej zaś od adwokatów wymagane są specjalne kwalifikacje, określone $w$ normach specjalnych tego trybunału 26 i nie zawsze adwokaci niższych instancji będą te kwalifikacje posiadać.

3. Adwokaci działający na forum kościelnym wymagają albo ogólnego zatwierdzenia ordynariusza $\mathrm{m}$. do występowania we wszystkich sprawach nie wyjętych, albo zatwierdzenia do obrony konkretnej sprawy. Zdaniem Robertiego zatwierdzenie do obrony jednej, określonej sprawy dotyczy tylko jednej instancji i wymaga odnowienia w następnej ${ }^{27}$. Zgodnie $z$ normą 4 , w trybunałach amerykańskich ponowne zatwierdzenie nie będzie potrzebne.

Norma 5. Notariusz ma zachować dla trybunalu pisemny protokól wszystkich akt procesu i sprawy, ze specjalnym zwróceniem uwagi na nazwiska, daty $i$ miejsca, jak również na autentyczność dokumentów i zeznańn. Wprawdzie akta nie uznane przez notariusza za autentyczne sa nieważne, wystarczy jednak, ̇̇eby odpisy tych akt byly uznane za autentyczne przez jedno oświadczenie notariusza na końcu sprawy.

Przepis ten ułatwia prace notariusza w procesie $\mathbf{i}$ udziela jego działalności większego kredytu zaufania. „Poszczególne karty procesu - zastrzega kan. 1643, § 1 - mają być ponumerowane i każda karta ma być zaopatrzona $w$ podpis notariusza $z$ pieczęcią trybunału". Jak wielką wagę przypisywali kanoniści w procesic funk-

25 Roberti F., dz. cyt., s. 567; Goyeneche S., dz. cyt., s. 164; Noval J., Commentarium Codicis Iuris Canonici, De processibus, Augustae Taurinorum 1920, t. I, s. 183.

${ }^{26}$ Art. 54-56 Norm Trybunału Roty Rzymskiej (AAS 26 (1934) 464465 ).

27 Roberti F., dz. cyt., s. 567. 
cji notariusza, niech świadczy cytat z komentarza Cappello: „Wszystkie akta mają być należycie podpisane tak, że nie posiadają mocy i wartości, jeśli brak właściwie złożonego podpisu. Notariusz musi podpisać wszystkie i poszczególne akta i to zawsze ostatni, jak gdyby stwierdzając wiarogodność podpisów złożonych przez innych" 28.

Według normy 5 wystarczy, jeśli notariusz potwierdzi autentyczność całości akt na końcu sprawy.

Norma 6. Ordynariusz winien postarać się o wystarczajaca ilość sędziów, obrońców i adwokatów tak, by każda prośba o orzeczenie nieważności mogła być natychmiast przyjęta lub odrzucona, a decyzja podjęta $w$ ciagu sześciu miesięcy od przyjęcia prośby.

Nowością tej normy są terminy sądowe. Przysłówek „quantotius" - możliwie szybko, im prędzej tym lepiej, znajdujący się w art. 61 Instrukcji Provida, został tu zastąpiony przez „promptly" - natychmiast. Określa on termin przyjęcia lub odrzucenia skargi powodowej. Termin ten jednak stanowi, jak się wydaje, proste życzenie, gdyż norma ósma mówi wyraźnie, ̇̇e „prośba o orzeczenie nieważności... má być przyjęta lub odrzucona przez sędziego $w$ ciągu trzydziestu dni następujących po jej przedłożeniu".

Termin sześciu miesięcy dotyczy czasu trwania pierwszej instancji. Jest to norma skracająca o trzy czwarte termin przepisany w kan. 1620 na załatwienie sprawy w pierwszej instancji 29. Wydaje się, że termin ten jest obowiązujący dla trybunału, ale można do niego zastosować warunek ,salva iustitia", zawarty w kan. 1620, tzn. że termin ten może ulec przedłużeniu, gdy sama sprawiedliwość domaga się dłuższego czasu na instrukcję procesu, lub gdy został on przerwany ze słusznych przyczyn.

Norma 6 zdaje się też odwoływać przepis kan. 1574, § 1 zezwalający na mianowanie $w$ diecezji tylko dwunastu sędziów. Norma mówi wyraźnie, że ordynariusz ma się postarać o taką ilość sędziów, jaka będzie wystarczająca w stosunku do potrzeb diecezji, a więc nie jest pod tym względem ograniczony żadnym przepisem prawa.

Norma 7. Pierwszy wlaściwy trybunal, któremu strona przedstawila prośbe, ma obowiazek przyjać ja lub odrzucić. Wlaściwość trybunału pierwszej instancji jest określona przez staly pobyt każ-

${ }^{28}$ Cappello F., Praxis processualis, Taurini 1968, wyd. 2, s. 7, ก. 11.

${ }_{99}$ Trudno się zgodzić z opinią Lefevre C., dz. cyt., s. 571, że ani Kodeks, ani Instrukcja Provida nie przepisuja żadnego terminu do przeprowadzenia procesu małżeńskiego. Czyżby norma kan. 1620 nie miała zastosowania $\mathrm{w}$ tym procesie? 
dego $z$ malżonków, przez miejsce zawarcia malżeństwa, lub przez dekret sędziego któremu prośba została przedstawiona, że jego trybunał jest do osądzenia sprawy bardziej zdatny niż inny. W tym ostatnim wypadku jednak sędzia nie może wydać takiego dekretu, bez otrzymania uprzednio zgody swojego wlasnego ordynariusza, zgody ordynariusza petenta i zgody sędziego przewodniczqcego.

1. Ustawodawca wprost i wyraźnie mówi o obowiązku przyjęcia skargi powodowej, przez pierwszy właściwy trybunał do którego zwróci się strona. Nie jest to przepis nowy, bo wynikał już $\mathrm{z}$ ogólnych norm procesowych, a mianowicie $\mathrm{z}$ kan. 1709, gdzie jasno powiedziano, że ,sędzia lub trybunał, po stwierdzeniu, że sprawa podlega jego właściwości i powód ma prawo prowadzenia procesu, możliwie szybko ma (debet) przyjąć skargę lub ją odrzucić". Obowiązek ten daje właściwemu trybunałowi prawo do rozpatrzenia $i$ rozstrzygnięcia sprawy, $w$ momencie, gdy pozwany otrzyma wezwanie trybunału. Równocześnie wygasa też $w$ tej sprawie właściwość innych trybunałów, które do chwili doręczenia wezwania byly równie kompetentne do prowadzenia procesu, jak ten trybunał, który sprawę przejął (kan. 1568 i art. 11 Instrukcji Provida).

2. Poważnym wyłomem $w$ ustawodawstwie powszechnym jest określenie nowych przepisów właściwości trybunału w sprawach małżeńskich.

Pojęcie stałego lub tymczasowego zamieszkania (domicilium vel quasi domicilium), zastąpiono tu określeniem stały pobyt (residence).

Zyskuje się więc właściwy trybunał $\mathrm{w}$ sprawach małżeńskich przez faktyczny pobyt na terenie diecezji, ale pobyt, który ma cechy trwałości. Nie wchodzi więc $w$ rachubę tylko pobyt aktualny o charakterze nie trwalym, wchodzi natomiast taki pobyt, który posiada cechy pewnej trwałości, chociaż wiadomo, że nie przekroczy pół roku. Jest to więc coś więcej niż pobyt aktualny, mniej zaś niż zamieszkanie tymczasowe.

Obok stałego pobytu, innym tytułem właściwości trybunału jest według normy siódmej, tak jak w Kodeksie, mi e j s ce $\mathrm{z} \mathrm{a} \mathrm{w} \mathrm{a} \mathrm{r-}$ c i a m a łż é st wa (kan. 1564, § 1, kan. 1964 i art. 3 Instrukcji Provida).

Drugą nowością dotyczącą właściwości trybunałów jest możliwość jej rozszerzenia (prorogatio competentiae), o ile trybunał nie posiada żadnego $\mathrm{z}$ poprzednich tytułów właściwości, ale ,,j es t d o osadzenia sprawy bardziej zdatny (better able) niz jakikolwiek inny".

Reguła ta jest dla dobra stron i może się $\mathrm{w}$ niektórych wypadkach wielce przysłużyć szybszemu rozstrzygnięciu sprawy. By 
jednak sędzia mógł wydać dekret $\mathrm{w}$ tej sprawie, musi otrzymać na to zgodę własnego ordynariusza, a nadto zgodę ordynariusza i przewodniczącego trybunału petenta.

Norma nic nie mówi o zgodzie stron procesowych, słusznie jednak zauważa Lefebvre, że taką zgodę należy $\mathrm{w}$ tym wypadku z góry założyć, sędzia bowiem nie będzie się zajmował sprawą, bez uprzedniego otrzymania skargi powodowej. Gdyby pozwany sprzeciwiał się dekretowi, należy wziąc pod uwagę zasadę kan. 1559, $\S 3$, że „powód winien dochodzić swych praw przed trybunałem pozwanego", a jeśliby pozwany posiadał kilka trybunałów wlaściwych do rozpatrzenia jego sprawy, powodowi przysługuje prawo wyboru trybunału (kan. 1559, § 3) ${ }^{30}$.

Warto tu zwrócić uwage na fakt, że podobne przedłużenie właściwości miało miejsce w prawie dekretałów. „W poprzednim prawie - pisze Wernz-Vidal - istniało forum prorogationis, mocaz którego iurysdykcja sędziego rozszerzała się na osoby ,sprawy, czas lub miejsce, w stosunku do których nie był właściwy, albo na zasadzie wyraźnej umowy stron, albo na zasadzie rozpatrywania sprawy przez sędziego niewłaściwego, któremu strony, zwłaszcza pozwany, świadomie i dobrowolnie, bez pomyłki lub przymusu, przynajmniej milcząco się poddały, nie wnosząc przeciwko niemu zarzutu braku właściwości" ${ }^{31}$.

Norma 8. Każdy matżonek, bez zastrzeżeń, może się starać o orzeczenie nieważności swojego malżeństwa. By to uczynić, winien uciec się do uslug adwokata. Prośba o orzeczenie nieważności, wskazująca na tytuł lub tytuly nieważności i źódla dowodu, ma być przyjęta lub odrzucona przez sędziego $w$ ciagu trzydziestu dni następujacych po jej przedlożeniu $i$ po konsultacji $z$ adwokatem i obrońca. Rekurs przeciwko odrzuceniu prośby można wnieść do trybunalu drugiej instancji. W ciagu trzydziestu dni od rekursu, odrzucenie prośby ma zostać podtrzymane, lub sprawę należy odestać do natychmiastowej instrukcji przez trybunal pierwszej instancji.

W związku z tą normą dwie ważne kwestie wymagają omówienia: 1) zdolność małżonków do zaskarżenia swego małżeństwa i 2) udział adwokata $\mathrm{w}$ procesie małżeńskim.

1. Kodeks w kan. 1646 stanowi, że czynności procesowe może podejmować każdy, o ile nie zabrania mu tego prawo kanoniczne. Jak wiadomo, istnieje $\mathrm{w}$ kan. 1971, $\S 1$ przepis, potwierdzony $\mathrm{i}$ uściślony $\mathrm{w}$ art. 37 Instrukcji Provida, oraz $\mathrm{w}$ odpowiedzi $\mathrm{Pa}-$ pieskiej Komisji Interpretacyjnej $\mathrm{z}$ dnia 27 lipca 1942 r. ${ }^{32}$, że

${ }^{30}$ Le fe bvre C., dz. cyt., s. 573-574.

31 W e r n z F. - Vid a 1 P., dz. cyt., s. 67.

32 AAS 34 (1942) 241. 
małżonek jest niezdolny do zaskarżenia nieważności swego małżeństwa, jeżeli sam byl bezpośrednią i umyślną przyczyną zrywającej przeszkody małżeńskiej lub samej nieważności małżeństwa. „Główną racją uzasadniającą ten przepis - jak stwierdza Rota Rzymska w jednym ze swoich wyroków - jest to, ze jest rzeczą jak najbardziej niewłaściwą i niebezpieczną, zapewniać sobie bezkarne naruszenie prawa" 33 .

Podobnie też, w myśl art. 35, § 3 Instrukcji Provida, „nie mogą występować $\mathrm{w}$ charakterze powoda $\mathrm{w}$ sprawach małżenskich niekatolicy bądź ochrzczeni, bądź nie ochrzczeni". Uzasadnieniem tego ograniczenia jest kan. 87, stanowiący że „w Kościele Chrystusowym czlowiek staje się osobą ze wszystkimi prawami i obowiązkami chrześcijańskimi przez chrzest, chyba że, gdy chodzi o prawa, stoi na przeszkodzie brak jedności z Kościołem lub została przezeń nałożona cenzura".

Otóż w normie ósmej obydwa te ograniczenia zostały zniesione. Każdy małżonek bez zastrzeżeń, może się starać o orzeczenie nieważności swojego małżeństwa.

Kanonowi 1971, § 1 od dawna już zarzucano zbyt daleko idącą surowość, która kontrastuje $\mathrm{z}$ zasadniczą, przychylną postawą Kościoła wobec człowieka i wyrozumiałością dla jego słabości ${ }^{34}$. Wiadomo również, że przepisy tego kanonu mocno komplikują pracę trybunałów kościelnych i tak przyjmujących do rozpatrzenia, chociaż okrężną drogą poprzez rzecznika sprawiedliwości, w praktyce wszystkie sprawy, w których małżonkowie byli umyślną i bezpośrednią przyczyną nieważności ich związku.

Także i art. 35, § 3 Instrukcji Provida nie wytrzymał naporu zasad ekumenizmu. Usunięcie tego ograniczenia staje się tym bardziej zrozumiałe, że dokonuje się ono na terenie Stanów Zjednoczonych, gdzie od lat problemy ekumeniczne były nabrzmiałe i domagały się konkretnych rozwiązań, chociaż nie są one obce i reszcie Kościoła.

2. Podobnie ogólnokościelne znaczenie ma sp rawa udziału a d wokata w procesie małżeńskim. Uprzywilejowane stanowisko jakie $\mathrm{w}$ tym procesie zajmuje obrońca węzła małżeńskiego, przy równoczesnym braku przymusu adwokackiego, mogło być i było niejednokrotnie powodem szkód dla małżonków. By tej ewentualności uniknąć norma stanowi, że celem przeprowadzenia procesu o orzeczenie nieważności swojego małżeństwa, strona "winna uciec się do usług adwokata". Tak sformułowany przepis nie zdaje się jeszcze wskazywać na wprowadzenie $w$ kościelnych trybunałach amerykańskich przymusu adwokackiego. Dalsze jed-

33 c. M or a no, Nullitatis matrimonii, diei 23 ianuarii 1931, SRR Dec. (23), s. 261.

34 J e m ol o C., Il matrimonio nel diritto canonico, Milano 1941, s. 392. 
nak normy ,które przytoczę na swoim miejscu, pozwalają wysnuć wniosek, że proces małżeński bez udziału adwokata jest nie do pomyślenia. Uprawnienia adwokata uległy istotnemu poszerzeniu, $\mathrm{a}$ on sam stał się równoważnym partnerem obrońcy węzła w procesie.

Norma ósma zastrzega na razie, że adwokat ma być przez trybunał konsultowany $w$ sprawie przyjęcia lub odrzucenia skargi powodowej, na równi z obrońcą węzła małżeńskiego.

Norma 9. Rzecznik sprawiedliwości może żadać orzeczenia nieważności malżeństwa, jeśli uzna, że będzie to dla dobra pobulicznego.

Norma, jak się wydaje, zmienia istotnie rolę rzecznika sprawiedliwości w stosunku do spraw małżeńskich. Kan. 1971, § 1 pozwala działać rzecznikowi $w$ wypadku istnienia przeszkód $z$ natury swej publicznych. Art. 38-40 Instrukcji Provida ograniczają swobodę działania rzecznika sprawiedliwości całym szeregiem warunków, w których może on oskarżać małżeństwo, opierając się na doniesieniu, przy czym ocena, czy oskarżenie takiego domaga się dobro publiczne, należy do ordynariusza.

Norma pozostawia tę ocenę rzecznikowi i nie uzależnia ewentualnego oskarżenia od żadnych innych warunków poza tym, że orzeczenie nieważności małżenstwa, jest uzasadnione dobrem publicznym.

Ilekroć zatem „małżonkowie nie chcą, albo nie mogą $z$ różnych przyczyn żądać orzeczenia nieważności własnego małżeństwa", może to za nich zrobić rzecznik sprawiedliwości ${ }^{35}$.

Norma 10. Jeśli pozwany sprzyja sprawie, winien mieć sposobność wyboru adwokata przed określeniem ścisłego tytułu nieważności. Jeśli pozwany nie popiera sprawy, sędzia przejdzie do tego określenia zgodnie z następna regula.

Norma 11. W ciagu miesiąca po przyjęciu prośby, sędzia po konsultacji $z$ adwokatem i obronca, określi ścisty tytul lub tytuły nieważności malżeństwa, dokumenty które należy zebrać i świadków do przestuchania. Podczas trwania procesu, sędzia może dolaczyć dodatkowy tytuł lub tytuły nieważności.

Ponownie w obydwu normach ujawnia się rola adwokata. Razem $z$ obrońcą wezła bierze on udział $w$ konsultacjach przed ustaleniem przez sędziego tytułów ewentualnej nieważności małżeństwa, określeniu dokumentów jakie będą przedstawione $\mathrm{w}$ procesie i sporządzeniu listy świadków. Jeśli pozwany wybierze sobie ad-

${ }^{35}$ Le f e bvre C., dz. cyt., s. 576. 
wokata innego niż ten który broni powoda, dwaj adwokaci i jeden obronca będą brać udział w tych ustaleniach.

Norma przepisuje też nowy termin, a mianowicie wymaga, by zawiązanie sporu nastąpiło $\mathrm{w}$ ciągu $30 \mathrm{dni}$ od przyjęcia prośby.

Dużym ułatwieniem na przyszłość, jest możli wość dołąc z e nia przez sędziego podczas trwania procesu, nowego tytułu, lub nowych tytułów nieważości i to bez konieczności uzyskania zgody pozwanego i obrońcy węzła, ale po przeprowadzeniu $z$ adwokatem $i$ obrońcą konsultacji i $z$ zachowaniem $w$ takim wypadku przepisanych prawem formalności ${ }^{36}$.

Norma 12. W każdej chwili podczas procesu, powód może prosić o przeniesienie sprawy $z$ jednego do drugiego wtaściwego trybunalu. Tego pozwolenia można udzielić pod warunkiem, że usprawiedliwiaja to poważne racje, że zostal wystuchany obrońca węzła i że ordynariusz a quo i przewodniczacy obydwu trybunatów $i$ druga strona, wyrazili na to zgodę.

Przeniesienie sprawy do innego wlaściwego trybunału wymaga zatem formalnej zgody czterech asób, wysłuchania obrońcy węzła i zaistnienia poważnej racji, jest jednak możliwe bez interwencji Sygnatury Apostolskiej.

Nie wydaje się możliwe przeniesienie sprawy do trybunału, który mógłby dekretem uznać swą właściwość na zasadzie normy 7mej. Wprawdzie przeniesienie sprawy może nastąpić „w każdej chwili podczas procesu", ale norma 7 mówi wyraźnie o tym, że trybunał może dekretem uznać swą właściwość w odpowiedzi na skargę powodową stron.

Norma 13. Zeznania stron i świadków winny być zbierane przez sędziego skoro tylko to jest możliwe, $w$ siedzibie trybunalu lub gdzie indziej. Osoby należy wezwać do zlożenia przysięgi przed zlożeniem zeznań, chyba że sędzia postanowi inaczej. Adwokat, chyba że sędzia postanowi inaczej $i$ obrońca, maja prawo być obecni przy przestuchaniu stron i świadków. W wypadku gdy adwokat. jest obecny, obroñca wezla musi być conajmniej wezwany. Pytania zadawane przez sędziego winny być oparte na informacjach $i$ pytaniach dostarczonych przez adwokata $i$ obroncę. Strony $i$ świadkowie moga być także pytani bezpośrednio przez adwokata $i$ obron$c e ̨$, pod kierunkiem sędziego. Jeżeli sędzia nie może osobiście przesluchać świadka, do dokonania tego może wyznaczyć kompetentnego delegata.

Normy ogólne kanonicznego procesu sądowego w kan. 1744 stanowią o przysiędze, że sędzia „ilekroć w sprawach spornych chodzi

36 L. ef e bvre C., dz. cyt., s. 577 . 
o dobro publiczne, musi jej żądać od stron". W procesie małżeńskim, w którym jak wiadomo zawsze chodzi o dobro publiczne, Instrukcja Provida w art. 110 zmniejsza ten obowiązek przez klauzulę „o ile poważna racja nie zaleca inaczej”. Jest rzeczą zrozumiała, że o istnieniu takiej racji decyduje sędzia i na jej podstawie może zrezygnować przy przesłuchaniu stron $z$ odebrania od nich przysięgi.

O świadku natomiast kan. 1767, § 1 mówi, że „zanim zezna, musi złożyć przysięgę, iż powie całą i samą prawdę".

Norma trzynasta stawia sprawę przysięgi stron i świadków na równi. Sędzia winien wezwać te osoby do złożenia przysięgi, może jednak, według własnego uznania, $z$ takiego wezwania zrezygnować. Nie wydaje się prawdopodobne, by kwestia odebrania przysięgi od stron i świadków była uzależniona od subiektywnego nastawienia sędziego do sprawy czy osób zainteresowanych, muszą więc za wyborem jednej lub drugiej drogi przemawiać jakieś racje, nie muszą to być już jednak racje poważne.

Druga sprawa poruszona przez norme, to rola a dwokata w p r ocesi e. Wzrasta ona do tego stopnia, że adwokat idzie już krok $\mathrm{w}$ krok $\mathrm{z}$ obrońcą węzła. Obydwu norma przyznaje na równi:

1) prawo do obecności podczas przesłuchania stron i świadków;

2) prawo do dostarczania informacji i pytań, na których sędzia oprze przesłuchanie;

3) prawo do bezpośredniego stawiania pytań stronom i świadkom, pod kierunkiem sędziego.

Dwa pierwsze spośród wymienionych uprawnień obrońca węzła już posiadał na zasadzie art. $70, \S 1$, n. 1 Instrukcji Provida, wedlug której „obrońca węzła ma uczestniczyć w przesłuchaniu stron, świadków i biegłych, przedstawiać sędziemu pytania zamknięte i opieczętowane, otwierane przez sędziego podczas przesłuchania".

Adwokat $\mathrm{w}$ obydwu tych czynnościach, jak dotąd, nie mógł brać udziału, chyba w drodze wyjątku, za zezwoleniem sędziego (kan. 1771 i art. 128 Instrukcji Provida).

Trzecie uprawnienie, tzn. możliwość bezpośredniego stawiania pytań stronom i świadkom podczas przesłuchania i pod kierunkiem sędziego, zostało przyznane adwokatowi, ale także dopiero teraz i obrońcy węzła. Dotychczasowe ustawodawstwo wymagało, by obrońca biorący udział $\mathrm{w}$ przesłuchaniu, wszelkie pytania jakie miał do przesłuchiwanych, kierował zawsze przez sędziego (art. 101 Instrukcji Provida).

Norma zdaje się także dopuszczać sytuację, w której ani adwokat, ani obrońca nie będą obecni przy przesłuchiwaniu. Wynika to ze zdania: „w wypadku gdy adwokat jest obecny, obrońca węzła musi być co najmniej wezwany”, oraz z klauzuli: „chyba że sędzia postanowi inaczej", przy pomocy której Ustawodawca zastrzega dla 
sędziego możliwość odmówienia adwokatowi i obrońcy prawa obecności podczas przesłuchania. Odmowa obecności musi być jednak uzasadniona i można się od niej odwołać do kolegium ${ }^{37}$.

Całość przepisów dotyczących przesłuchania stron i świadków świadczy o tym, że w kościelnych trybunałach amerykańskich będzie ono wyglądać inaczej niż obecne, oparte na zasadach Kodeksu. Będzie ono miało formę audiencji, podczas której, pod kierunkiem sędziego, strona lub świadek, oprócz odpowiedzi na pytania sędziego, będzie musiał wyjaśniać cały szereg szczegółów ważnych dla obrońcy i adwokata, w odpowiedzi na pytania zadawane bezpośrednio przez nich.

Norma 14. W nastepstwie konsultacji $z$ adwokatem $i$ obrónca, sędzia określi znaczenie odmowy stron $i$ (lub) świadków zlożenia zeznań $i$ przystapi, jeśli to konieczne, bez ich zeznania, do zamknięcia postępowania $w$ sprawie.

Norma w sprawach zasadniczych nie wychodzi poza obowiąujące przepisy kan. 1743, $\$ 2$ i art. 112 Instrukcji Provida, oraz kan. 1860 i $1984, \S 2$. Nadal sędzia i tylko on ocenia znaczenie odmowy złożenia zeznańń przez stronę lub świadków, on też decyduje o zamknięciu postępowania dowodowego. Adwokat i obrońca, także i na tym etapie procesu uzyskują równe prawa, obydwaj mają być wysłuchani przed podjęciem przez sędziego decyzji.

Norma 15. Adwokat $i$ obrońca moga badać akta sprawy $w k^{-}$ dym stadium procesu, chyba że $w$ poszczególnych wypadkach sędzia postanowi inaczej.

Jak dotąd kan. 1969, n. 1 i art. $71, \S 1$ n. 1 stanowiły, że obrońca węzła ma prawo zawsze i w każdym momencie sprawy badać akta procesu, nawet nie publikowane. Adwokat zyskuje dziś to samo prawo. Pozwoli to na sprawniejszą instrukcje procesu, zwłaszcza zaś na wydanie wyroku w krótkim czasie po publikacji. Skoro bowiem nie tylko obrońca węzła, ale i adwokat będzie miał wgląd w akta sprawy, na czas i przed publikacją wskażą oni ewentualne nowe dowody, których istnienie wyszlo na jaw już podczas trwającej instrukcji 38 .

Nie wyklucza to jednak moźliwości zgłaszania przez strony postulatów dotyczących dodatkowej instrukcji procesu po publikacji, gdyż strony same nie mają wglądu w akta sprawy aż do ich ogłoszenia ${ }^{39}$. Może się więc zdarzyć, że adwokat nie dostrzeże

${ }^{37}$ L ef e bvre C., dz. cyt., s. 579.

${ }^{38}$ Le f e b vre C., dz. cyt., s., 582.

39 Ani Kodeks, ani Instrukcja Provida wprost takiego zakazu nie zawieraja, wynika on jednak jasno $\mathrm{z}$ tajnego charakteru procesu małżenskiego. Strony procesowe moga wprawdzie posiadać pełne wiadomości o sprawie od adwokata, nawet w wypadku gdy część świadectw jest za- 
czegoś, co dla strony, po zapoznaniu się z treścią zebranych dowodów okaże się ważne.

Norma 16. Sędzia dokladnie rozważy zeznania każdego świadka. Swiadectw dotyczących wiarogodności stron $i$ świadków należy wymagać, jeśli wedlug uznania sędziego wydaja się one konieczne lub użyteczne.

Prawo powszechne nie wymagało świadectw kwalifikacyjnych dla stron, nalegało natomiast mocno na to, by sędzia $\mathrm{z}$ urzędu żądal świadectwa „religijności, prawości i wiarogodności” dla wszystkich świadków (art. 136, § 1 Instrukcji Provida).

Norma nie rezygnuje $\mathrm{z}$ ważności świadectw kwalifikacyjnych, przeciwnie, docenia ich wartość tak w stosunku do świadków, jak $\mathrm{i}$ w stosunku do stron ${ }^{40}$, pozostawia jednak sędziemu w tej sprawie pewną swobodę działania. On sam mianowicie ma ocenić, czy i dla kogo trzeba lub będzie przydatne świadectwo kwalifikacyjne, chociaż nie ulega wątpliwości, że zarówno obrońca węzła jak i adwokat mogą się domagać od sędziego, by do akt sprawy takie świadectwo było załączone.

Norma 17. W wypadkach dotyczacych psychicznej lub fizycznej niemocy $i$ braku zdolności do konsensu, sędzia, po konsultacji $z$ adwokatem $i$ obronca, wyznaczy jednego lub więcej bieglych, by przestudiowali akta sprawy $i$ przedłożyli o tym pisemna relację. Jeśli to wskazane, biegly ten winien zbadać stronę lub strony $w$ tej sprawie $i$ wlaczyć do swej relacji wyniki tego badania. Ustne zeznania może biegly zlożyć tylko wówczas, gdy jego relacja wymaga wyjaśnienia lub uzupelnienia. W następstwie konsultacji $z$ adwokatem i obrońca, sędzia może wyznaczyć dodatkowych bieglych.

Norma wprowadza kilka ważnych zmian, które nie będą bez wpływu na bieg procesu małżeńskiego.

1. W sprawach prowadzonych $z$ tytułu choroby psychicznej, sędzia, jak dotąd, jest zobowiązany do powołania jednego biegłego, lub w trudniejszych wypadkach dwóch biegłych, którzy ,,chorego, jeśli zajdzie potrzeba i akta jego sprawy, które dają podejrzenie amencji, zbadają zgodnie z zasadami wiedzy" (kan. $1982 \mathrm{i}$ art. 151 Instrukcji Provida). W sprawach zaś prowadzonych $z$ tytułu niemocy fizycznej, bez względu na rodzaj wypadku, sędzia ma obo-

chowana w tajemnicy (por. Torre J., Processus matrimonialis, Neapoli 1956, wyd. 3 , s. 281-282) niemniej, nie pozbawia to stron prawa do żądania uzupeinienia instrukcji procesu do publikacji akt (por. kan. 1858 Kodeksu i art. 175 Instrukcji Provida).

40 Ustawodawca ma tu oczywiscie na myśli świadectwa oparte na prawdzie, na rzeczywistej znajomości osób, o które chodzi (por. Tor re J., dz. cyt., s. 288). 
wiązek powołania dwóch biegłych lekarzy, jeśli chodzi o mężczyzn, lub dwóch biegłych akuszerek (albo również dwóch biegłych lekarzy), jeśli chodzi o kobiety, którzy muszą dokonać osobistych badań (kan. 1979, § 1-2 i art. 150 Instrukcji Provida).

Norma zrównuje wypadek niemocy z chorobą psychiczna i wymaga udzialutylkojednegobiegłego w procesie $z$ tych ty tułów, pozwalając równocześnie, jeśli zachodzi rzeczywista potrzeba, na udział dwóch, lub większej ilości biegłych.

2. Wyznaczenia biegłego, jak również powołania dodatkowych biegłych dokonuje sędzia, ale znów po konsultacji $\mathrm{z}$ adwokatem i obrońcą węzła.

3. Dotychczas biegli, w sprawach z tytułu niemocy fizycznej byli zobowiązani badać stronę lub strony osobiście, z tytułu choroby psychicznej można było czasem poprzestać na badaniu akt sprawy. I tu nastąpiło zrównanie roli biegłych. W obydwu wypadkach wystarcza przestudiowanie akt sprawy i przedłożenie o tym sędziemu pisemnej relacji. Ale i tu, jeśli to wskazane, badania osobiste mogą być przez sędziego zadekretowane.

4. Przesłuchanie biegłych zostaje skreślone z listy obowiązujących czynności procesowych, nakaznych art. 152 Instrukcji Provida. Może ono jednak mieć miejsce, ale tym razem jedynie jako środek do wyjaśnienia lub uzupełnienia przedłożonej przez biegłego na piśmie relacji.

Norma 18. Kiedy po konsultacji $z$ adwokatem $i$ obrońcq sedzia zadecydowal, że wszystkie konieczne $i$ dostępne dowody zostaly zebrane, stronom należy zezwolić na czytanie akt, chyba że wedlug uznania sędziego grozi to naruszeniem prawa tajemnicy. Sędzia winien rozpatrzyć $\dot{z} y c z e n i a$ stron $w$ stosunku do uzupelniajacej instrukcji, przed zamknięciem postępowania $w$ sprawie.

Sędzia, przed zamknięciem postępowania w sprawie jest zobowiązany wysłuchać adwokata i obrońcy. Jest to jedyna nowość jaką zawiera norma $\mathrm{w}$ stosunku do dotychczasowego ustawodawstwa.

Norma 19. Adwokat i obrońca maja przedłożyć niezależnie od siebie pisemna obrona, w ciagu miesiqca po przedstawieniu wszystkich dowodów; należy też dać możliwość repliki, której trzeba dokonać $w$ ciagu dwóch tygodni.

Norma 20. W następstwie tych konsultacji $z$ adwokatem i obrońca na które zezwala prawo i które sędzia uzna za konieczne, winien on wydać wyrok $w$ ciqgu jednego miesiaca od przedstawienia obrony i replik. 
1. Obydwie te normy stanowią ukoronowanie kariery, jaką zrobil adwokat $\mathrm{w}$ obecnej reformie. Ma więc prawo, na równi $\mathrm{z}$ obrońcą $\mathrm{i}$ w tym samym co on czasie, przedlożyć trybunałowi obronę, względnie później, również na równi $\mathrm{z}$ obrońcą $\mathrm{i}$ w tym samym czasie, replikę. Oznacza to uchylenie kan. 1984, § 1 który zastrzegał, że „obrońca węzła posiada prawo, by w stosunku do przytaczania (sc. dowodów), żądania i odpowiadania, tak na piśmie, jak w obronie ustnej, był wysłuchiwny jako ostatni" (kan. 1984, § 1) ${ }^{\mathbf{4}}$.

Norma ta znosizatem calkowicie uprzywilejowane stanowisko obrońcy wezła małżenskiego w procesie małżeńskim, daje bowiem adwokatowi do dyspozycji wszystkie te środki, jakie posiadał obrońca i które często tylko jemu przysługiwały.

2. Obydwie normy wprowadzają także kilka dalszych, nowych terminó sąd ow y ch:

a) obronę należy przedłożyć $w$ ciągu miesiąca po przedstawieniu wszystkich dowodów, czyli $\mathrm{w}$ przeciągu miesiąca po zamknięciu postępowania dowodowego;

b) repliki trzeba dokonać w ciągu dwóch tygodni;

c) wyrok winien być wydany w ciągu jednego miesiąca od przedstawienia replik, a gdyby ich nie złożono, od przedstawienia obrony.

Norma 21. Sędzie wyda swa decyzję zgodnie $z$ moralna pewnościq, osiagnięta na podstawie przeważajacej sily tych dowodów, które maja uznana wartość $w$ prawie i jurysdykcji.

Tekst normy brzmi dość niewinnie i na pierwszy rzut oka trudno się zorientować, że chodzi tu o zasadniczą sprawę nowej interpretacjikan. 1869, § 1 mówiącego o potrzebie posiadania przez sędziego moralnej pewności przy wyrokowaniu, a zwlaszcza o osłabienie siły słynnego kan. 1014, według którego „małżeństwo cieszy się przychylnością prawa, dlatego w wątpliwości należy się opowiedzieć za jego ważnością, dokąd nie udowodni się czegoś przeciwnego".

Konieczność nowej interpretacji tych kanonów wynika stąd, że norma uznaje za wystarczającą podstawę moralnej pewności „przeważającą siłę dowodów", przy czym zaznacza, że chodzi tu o dowody uznane $\mathrm{w}$ kanonistyce $\mathrm{i}$ że ich siła, ich wartość dowodowa, nie ulegają zmianie.

Jeżeli sędzia może uzyskać moralną pewność w oparciu o przeważającą siłę dowodów, to trzeba przyjąć, że poza tymi dowodami o przeważającej sile, istnieją w sprawie inne, prawdziwe dowody, chociaż posiadające siłę mniejszą i tym słabszym dowodom musi się przyznać prawdopodobną rację. Nieważność małżeństwa można

${ }^{41}$ L e f e bvr e. C., dz. cyt., 585 . 
więc orzec $\mathrm{w}$ oparciu o większe prawdopodobieństwo, a $\mathrm{w}$ konsekwencji zmienić należy pojęcie moralnej pewności, którą dotąd, za Piusem XII określano jako taki stan, który „wyklucza wszelką uzasadnioną wątpliwość twierdzenia przeciwnego". Jeśli więc norma mówi o moralnej pewności zaczerpniętej z przeważającej siły dowodów, to nie tylko nie wyklucza wszelkiej uzasadnionej wątpliwości twierdzenia przeciwnego, ale wprost uznaje mniejszą siłę rzeczywistych dowodów przeciwnych ${ }^{43}$.

Dla zilustrowania tej ważnej innowacji, pozwolę sobie przytoczyć prawie dosłownie uwagi, jakie na ten temat poczynił prof. Gordon.

Zasada przeważającej sily dowodów wzięta została $\mathrm{z}$ prawa procesowego Stanów Zjednoczonych, które $\mathrm{z}$ kolei zaczerpnęło ją $z$ ustawodawstwa brytyjskiego. Zasada ,preponderance of the evidence" ma specjalne znaczenie. Evidence w anglo-amerykańskiej terminologii procesowej nie jest równoznaczne $z$ lacińskim określeniem evidentia, a więc nie oznacza ostatecznego motywu z powodu którego uważamy coś za pewne; jest to raczej termin techniczny oznaczający dowody uzyskane poprzez przytoczenie faktów, zeznań $i$ dokumentów, które $w$ procesach mogą być dopuszczone, celem udowodnienia lub wykluczenia faktu, wokół którego toczy się spór. „Preponderance of the evidence" oznacza to, co w pewnym rodzaju spraw wymagane jest i wystarcza ze strony powoda do udowodnienia jego roszczeń. W procesach karnych należy wykazać że przestępstwo jest pewne, w sprawach spornych wystarczy, by strona na której spoczywa obowiązek dowodzenia, wykazała swą rację przez jakąś wyraźną przewagę dowodów czy argumentów tak, że jeśli argumenty obydwu stron są równe, pozwany ma być uwolniony od wszelkich zobowiązań a powód przegrywa sprawę ${ }^{43}$.

Norma 22. Każdy przypadek nieważności dotyczacy akt czy procesu, określony $w$ prawie pozytywnym, uważa sie za sanowany przez sam wyrok, pod warunkiem, $\dot{z} e$ nie zostat on uprzednio zakwestionowany.

Wyrok jest nieusuwalnie nieważny tylko wówczas gdy: 1) jego założenia sa bezpodstawne; 2) nie udzielono prawa do obrony; 3) sędzia zostal zmuszony, bądź pod wpływem sity fizycznej, baddź cięźkiej bojaźni do wydania swej decyzji; 4) sam wyrok nie dotyczy przedmiotu sporu. Nieważność opisana $w$ powyższym paragrafie może być zgloszona zawsze, badź $w$ formie skargi, bądź $w$ formie zarzutu.

I ta norma ma kapitalne znaczenie.

${ }^{42}$ L e f e b v r e C., dz. cyt., 586-587.

$43 \mathrm{G}$ ord on I., De nimia processuum matr. duratione, W: Periodica de re morali canonica liturgica 4 (1969) 703-704. 
W pierwszym rzędzie stanowi, że wy rok sanuje błędy i nieformalności, które zostały popełnione podczas trwania procesu i które, zgodnie z przepisami prawa, mogą spowodować nieważność akt czy nawet całego procesu, jeśli prawo pozytywne wiąże z tymi błędami czy nieformalnościami takie skutki prawne. Sanacja ma miejsce tylko wówczas, gdy przed wydaniem wyroku, nikt $\mathrm{z}$ zainteresowanych nie zglosil pretensji co do popełnionych błędów. Jeśli takie pretensje zostały wyrażone, sędzia będzie miał chowiązek usunąć błąd, zgodnie z przepisami Kodeksu. Gdyby mimo zaczepienia nieformalnego postẹpowania przez osoby zainteresowane, sędzia wydał wyrok bez uwzględnienia zgloszonych pretensji, sanacja nie następuje.

Ponadto norma wylicza taksatywnie cztery wypadki nieusuwalnej nieważności wyroku, oparte na prawie naturalnym.

Jeśli więc wyrok nie uwzględnia koniecznych elementów prawa naturalnego, a więc: opiera się na bezpodstawnych założeniach, przekreśla naturalne prawo stron do obrony, został wydany przez sẹdziego, który nie posiadal koniecznej swobody wyrokowania, albo wreszcie dotyczy innego przedmiotu sporu, jest nieusuwalnie nieważny.

Słuszniejsze wydaje się w tej sprawie stanowisko Robledy, który twierdzi, że $\mathrm{w}$ tych wypadkach należałoby raczej mówić o braku wyroku, o nieistnieniu wyroku, niż o jego nieważności, gdyź nie może istnieć to, co nie posiada istotnych, konstytutywnych elementów; w konsekwencji trzeba powiedzieć, że nie może być nieważne to, co nie istnieje ${ }^{44}$.

Norma 23. I. Gdy już apelacja zostala wystana do wyższego trybunalu $i$ sam trybunat zostal ukonstytuowany zgodnie $z$ norma trzeciq, wezwanie stron i zawiqzanie sporu winno mieć miejsce $w$ przeciagu jednego miesiaca.

Podczas zawiazania sporu, jeśli dalszych badan domagaja się albo strony, albo obrońca węzta, albo sam trybunal z urzędu, sprawe należy osqdzić zwyklym sposobem drugiej instancji. Instancja ta jednak nie powinna, jeśli możliwe, przekroczyć granicy sześciu miesięcy.

Jeśli dalsze badania nie sa wymagane, sędzia winien natychmiast zadekretować zamknięcie postępowania $w$ sprawie. W ciagu miesiaca od daty tego dekretu, trybunal, biorqc pod uwage obrone adwokata i uwagi obrońcy węzla, wyda nowy wyrok, zgodnie $z$ przepisami prawa.

II. W innych wyjatkowych wypadkach, kiedy wedlug osqdu

44 R obleda O., Quaestiones disputatae iuridico canonicae, Romae 1969 , s. $71-73$. 
obróncy węzła $i$ jego ordynariusza, apelacja przeciwko pozytywnej decyzji bylaby bezspornie zbyteczna, sam ordynariusz może prosić Konferencje Episkopatu, by $w$ tych poszczególnych wypadkach obrońca węzla zostat dyspensowany od obowiazku apelacji, tak by wyrok pierwszej instancji mógl być natychmiast wykonany.

Wbrew wyraźnym postulatom amerykańskim ${ }^{45}$, obowi ązek a pelacji obroncy węzła do II instancjizostał utrzymany jako zasada ogólna. W wyjątkowych wypadkach, gdy zdaniem obrońcy i ordynariusza miejsca apelacja od wyroku orzekającego nieważność małżeństwa byłaby bezspornie zbyteczna, Konferencja Episkopatu, na prośbę ordynariusza, w każdym wypadku z osobna, może $z$ wolnić obrońcę węzła od obowiązku a pela cji.

W praktyce sądowej nie brak wypadków, z których wyjściem będzie ta wyjątkowa reguła działania. Zachodzi pytanie, w jaki sposób prośba ordynariusza o dyspensę dla obrońcy będzie rozpatrywana przez Konferencję Episkopatu; czy przez Konferencję jako całość, $z$ zachowaniem zasady działania kolegialnego, czy raczej przez specjalnie wyznaczoną komisję? Wydaje się, że będzie to mogła załatwiać komisja. Wprawdzie Centralna Komisja Koordynacji Prac Soborowych i Interpretacji Dekretów Soborowych na pytanie „czy władza prawodawcza, przyznana w pewnych granicach Konferencjom Biskupów ... może być delegowana Komisjom biskupim powolanym przez te Konferencje, odpowiedziała negative ${ }^{46}$, ale co innego władza ustawodawcza, co innego zaś dyspensa od obowiązku apelacji.

Po otrzymaniu takiej dyspensy, ordynariusz powinien natychmiast zarządzić wykonanie wyroku, orzekając, że strony są stanu wolnego.

2. Jeżeli obrońca węzła apelował do II instancji, spór ma być rozpatrywany normalnym, kodeksowym trybem, ale tylko wówczas, gdy potrzebna jest dalsza instrukcja sprawy. Jeśli nikt nie domaga się dalszej instrukcji, należy zadekretować natychmiast zamknięcie postępowania. W obydwu wypadkach należy wziąć pod uwagę obronę adwokata i uwagi obrońcy węzła. W wypadku nie wymagającym dalszej instrukcji norma wyraźnie żąda wzięcia pod uwage stanowiska obrońcy $i$ adwokata, milczy natomiast $w$ tej sprawie w wypadku gdy instrukcja jest uzupełniana. Skoro jednak żąda interwencji adwokata $\mathrm{i}$ obroncy $w$ prostszym wypadku postępowania bez nowego materiału dowodowego, tym bardziej

${ }^{45}$ Gordon I., De nimia processuum matr. duratione, W: Periodica de re morali canonica liturgica, 4 (1969) 725.

46 AAS 60 (1968) 361. 
obecność tych osób w procesie z uzupełniającym materiałem dowodowym wydaje się konieczna ${ }^{47}$.

3. W instancji apelacyjnej, teoretycznie rzecz biorąc, może zaistnieć sytuacja, że trybunał będzie się składal $z$ jednego sędziego, podczas gdy w pierwszej instancji sądziło sprawę kolegium. Możliwość taka wynika $z$ określenia zawartego w normie, że trybunał apelacyjny ma być ukonstytuowany zgodnie $z$ normą trzecią, ta zaś przewiduje możliwość trybunału jednoosobowego. Jest to zresztą możliwość mieszcząca się, przynajmniej zdaniem niektórych autorów, w granicach ogólnych zasad procesowych kanonistyki 48.

4. Nowe t r rminy jakie przewiduje norma są następujące:

a) wezwanie stron i zawiązanie sporu w II instancji ma nastąpić w ciągu miesiąca od wysłania apelacji do wyższego trybunału;

b) II instancja, jeśli możliwe, nie powinna trwać ponad sześć miesięcy;

c) dekret zamknięcia postępowania w II instancji, jeśli nie jest potrzebna dodatkowa instrukcja, ma być wydany natychmiast, tzn. zaraz po zawiązaniu sporu;

d) wyrok w II instancji należy wydać w ciągu miesiąca od dekretu zamknięcia postępowania w sprawie;

e) wykonanie wyroku ma nastąpić natychmiast po otrzymaniu dyspensy dla obrońcy węzła, od obowiązku apelacji, w wypadkach nadzwyczajnych.

\section{Uwagi końcowe}

Normy postępowania w sprawach małzeńskich, zatwierdzone przez Stolice Apostolską dla diecezji Stanów Zjednoczonych Ameryki Północnej, są pierwszym, na szeroką skalę zakrojonym eksperymentem $\mathrm{w}$ dziedzinie procesu małżéskiego, dokonanym po Soborze Watykańskim II, podyktowanym potrzebami miejsca i czasu, przygotowanym jednak nie tylko na terenie USA, ale także przez ogólny klimat reformy prawa kanonicznego, istniejący w Kościele powszechnym już od wielu lat.

Jest rzeczą dyskusyjną, czy tak właśnie jak Normy dla Stanów Zjednoczonych, winny wyglądać przepisy procesu małzeńskiego w nowym kodeksie, nie ulega jednak wątpliwości, że szereg innowa-

47 L e fe bv re C., dz. cyt., s. 589 uważa, że z normy nie wynika jasno, czy nową obronę należy sporządzać, czy nie.

48 R oberti F., dz. cyt., s. 321; Vermeers ch A., - Creusen J., Epitome Iuris Canonici, Mechliniae 1956, wyd. 7, t. III, s. 25; Regatillo E., dz. cyt., s. 263; Coc ch i G., Commentarium in Codicem Iuris Canonici, t. IV - De processibus, Torino 1936, wyd. 2, s. 61; T o r qu ebia $\mathrm{P}$. - Naz R. - De Clercq C., Traité de Droit Canonique, T. IV - Des procès, des délits, des peines, Paris 1954, wyd. 2, s. 79. 
cji wprowadzonych przez te Normy, ułatwiłoby i skróciłoby prace we wszystkich trybunałach kościelnych.

Warto jednak zwrócić uwagę, że dzisiejszej, gdzieniegdzie kryzysowej sytuacji trybunalów kościelnych, nie można rozstrzygnąć samą tylko zmianą przepisów proceduralnych. Głębszym i kluczowym, jak sie wydaje, jest problem ludzi, którzy po odpowiednim przygotowaniu, mogliby podjąć w pełnym wymiarze godzin pracę w sądach diecezjalnych czy regionalnych, pojmując ją jako rzeczywiste duszpasterstwo $i$ wykonując $z$ pełną odpowiedzialnością.

i.

\section{DODATEK}

Reskrypt Rady dla Międzynarodowych Spraw Kościelnych

Consilium pro Publicis Ecclesiae Negotiis

N. $3320 / 70$

Attentis precibus Conferentiae Episcopalis Statuum Foederatorum Americae Septemtrionalis, quibus petitur ut, consideratis peculiaribus sui territorii necessitatibus, normis quibusdam, quae precibus adnectuntur, ad expeditiorem reddendum causarum de nullitate matrimonii cursum, in eodem territorio, tribunalia utantur, Ss. mus Dominus Noster Paulus Papa VI supradictis precibus annuere dignatus est, ad triennium et experimenti causa, concedendo facultates omnes necessarias et opportunas et derogando, quatenus opus est, iuri vigenti; cauto tamen ut de cetero, cum praedictis normis totus processus non exhauriatur, serventur iuris canonici praescripta. Idem Summus Pontifex statuit ut supradictae normae a die 1 iulii 1970 valere incipiant.

Velit autem Praeses Conferentiae expostulantis mittere quotannis Supremo Tribunali Signaturae Apostolicae relationem de causis in unoquoque Tribunali propositis, vel desertis, vel appellatis.

Ex Aedibus Vaticanis, die 28 Aprilis a.D. MCMLXX.

J. Card. Villot

Prefectus Consilii pro Publicis Ecclesiae

L. + S. Negotiis

II.

Normy postępowania $w$ sprawach małżńskich

Norm 1. The Diocesan Tribunal will consist of judges, a defender of the bond, a promoter of justice and notaries and all will be appointed to their offices by the Ordinary. The judges, defenders of the bond and promoter of justice shall be priestes; all, however, shall be endowed with those qualities required by law.

Norm 2. The Ordinary will, appoint a chief judge who will direct the work of the Tribunal and assign judges and defenders of the bond for individual cases.

Norm 3. A collegiate Tribunal must be constituted for each case. The Episcopal Conference, in accordance with faculties to be sought from the Holy See, may permit the competent ecclesiastical Tribunal 
to derogate from this norm for a specified period of time so that a case may be handled by a single judge.

The conditions are that: 1) there be a grave reason for granting the derogation; and 2) no formal opposition be expressed prior to the definitive sentence by either the judge, the defender of the bond, the promoter of justice or either of the parties.

Norm 4. If both parties are desirous of a declaration of nullity, one advocate may represent both. Unless a party decides otherwise, the advocate in first instance will also be the advocate in second instance. Advocates representing the parties will be those approved to work with marriage cases by the Ordinary or his delegate.

Norm 5. The notary for the Tribunal will preserve a written record of all procedural and substantive acts, with special regard to names, dates and places as well as the authenticity of documents and depositions. While acts not authenticated by the notary are null, it suffices that copies of these acts be authenticated by a single statement of the notary at the termination of the case.

Norm 6. The Ordinary will provide sufficient judges, defenders and advocates so that all petitions for declaration of nullity may be accepted or rejected promptly and decisions given within six months follwing acceptance of the petition.

Norm 7. The first competent Tribunal to which a party presents a petition has an obligation to accept or reject the petition. The competence of a Tribunal of first instance shall be determined by the residency of either party to the marriage, the place of the marriage or the decree of the judge to whom the petition is presented that his Tribunal is better able to judge the case than any other Tribunal. In this last instance, however, the judge may not issue such a decree without first obtaining the consent of his own Ordinary and the consent of the peitioner's Ordinary and chief judge.

Norm 8. Any spouse, wthout qualification, may seek a declaration of nullity of his marriage. To do so, he will employ the services of an advocate. The petition for the declaration of nullity indicating the basis or bases for nullity and the sources of proof is to be accepted or rejected by the judge within the thirty days following the presentation and after consultation with the advocate and defender. Recourse against the rejection of a petition may be made to the Tribunal of second instance. Within thirty days of recourse, rejection of the petition is to be sustained or the case is to be remanded for prompt instruction by the Tribunal of first instance.

Norm 9. The promoter of justice may petition that a marriage be declared null when he decides this will be for the public good.

Norm 10. If he is available and cooperative, the respondent will be given the opportunity to choose an advocate prior to the determination of the precise basis for nullity. If the respondent is not available and cooperative. the judge will proceed to this determination in accordance with the follwing rule.

Norm 11. Within a month after the acceptance of the petition, the judge, after consultation with the advocate and defender, will determine the precise basis or bases for the nullity of the marriage, the documents to be obtained, and the witnesses to be heard. During the 
course of the trial the judge may add an additional basis or bases for nullity.

$\mathrm{N}$ orm 12. At any time in the course of the trial, the petitioner may request that the case be tranferred from one competent tribunal to another competent tribunal. This permission will be granted prowided that a grave reason warrants it, that the defender of the bond has been heard and that it is agreeable to the other party, the Ordinary a quo and the chief judges of both tribunals.

Norm 13. The testymony of the principals and the witnesses will be taken by the judge as soon as available, either at the Tribunal or elsewhere. A person will be asked to take an oath before testifying unless the judge determines otherwise. The advocate (unless the judge determines otherwise) and the defender have the right to be present at the hearing of the principals and witnesses. In the event that the advocate is present, the defender of the bond must always at least be cited. Te questions proposed by the judge will be based upon the information and questions supplied by the advocate and the defender. The principals and witnesses may also be questioned directly by the advocate and the defender under the direction of the judge. When a judge is personally unable to take the testimony of a witness, be will appoint a competent delegate to do so.

Norm 14. Following consultation with the advocate and defender, the judge will determine the significance of the unwillingness of a principal and/or witnesses to testify and will, if necessary, proceed to the conclussion of the case without their testimony.

Norm 15. The advocate and the defender may examine the acts of the case at any stage of the process unless in particular cases the judge decides otherwise.

Norm 16. The judge will carefully weigh the depositions of each witness .Testimonials concerning the credibility of the principals and witnesses will be required if, in the opinion of the judge, they seem necessary or useful.

Norm 17. In cases involving physical or psychic impotence and lack of consensual capacity, the judge, after consultation with the advocate and the defender shall designate one or more experts to study the acts of the case and submit a written report thereon. When advisable, this expert will examine the party or parties to the case and will include in his report the results of his examination. The oral testimony of the expert is to be taken only ir his report requires clarification or implementation. Following consultation with the advocate and the defender, the judge may appoint additional experts.

$\mathrm{N}$ or $\mathrm{m}$ 18. When, after consultation with the advocate and the defender, the judge has decided that all necessary and available evidence has been obtained, the principals will be permitted to read the acts unless, in the opinion of the judge, there is danger of violation of the rights of privacy. The judge will consider the requests by the principals for further instruction before bringing the case to a coclusion.

Norm 19. The advocate and the defender will submit written briefs independently within one month after all evidence has been presented and will be given the opportunity of a rejoindre to be made within two weeks. 
Norm 20. Following whatever consultation with the advocate and the defender which is allowed by law and which he deems necessary, the judge will render a decision within one month after the presentation of the briefs and rejoinders.

Norm 21. The judge will render his decision according to moral certitude generated by the prevailing weight of that evidence having a recognized value in law and jurisprudence.

Norm 22. Any instance of nullity as defined in positive law with regard to acts or processes is considered sanated by the sentence itself provided that it was not previously challenged.

A sentence is irremediably null only when: 1. Its presuppositions were lacking grounds; 2 . the right of defense has been denied; 3 . the judge was coerced either by violence or grave fear to render his decision; 4. the sentence fails to address itself to the controversy in question.

The nullity descibed in the paragraph above may be perpetually proposed either as an action or as an exception.

Norm 23. I. Once an appeal has been made to a higher Tribunal and the Tribunal itself has been constituted in accord with Norm 3, the citation of the parties and the joining of issues shall take place within one month.

At the time of the joining of issues, if further investigations are requested either by the parties or the defender of the bond or the Tribunal itself ex officio, the case shall be heard in the ordinary manner of second instance. This instance, however, should not if possible exceed the limit of six months.

If further investigations are not required, the judge will immediately decree the case concluded. Within a month from the date of this decree, the Tribunal, taking into account the briefs and animadversions of the advocate and defender of the bond, shall issue a new sentence according to the norm of law.

II. In those exceptional cases where in the judgment of the defender of the bond and his Ordinary an appeal against an affirmative decision would clearly be superfluous, the Ordinary may himself request of the Episcopal Conference that in these individual cases the defender of the bond be dispensed from the obligation to appeal so that the sentence of the first instance may be executed immediately.

N.B. Tekst dodatku podaję za F. R. M c M a nus, Procedural Norms for Matrimonial Cases, opublikowanym w The Jurist, 30 (1970) 363369 .

\section{SUMMARY}

Procedural norms for matrimonial cases issued by the Holy See for the dioceses of the United States

The procedural norms issued by the Holy See for the dioceses of the United States of North America are mostly of local significance in the territory for which they have been issued. But as they were made public during the reform of the entire canon law, by the central legislative organ of the Church, they are of interest to all canonists because they suggest the development of future general legislation in the field of pronouncing the nullity of marriage. 
The norms issued for the USA are partly the result of the work of IInd Vatican Council and partly the result of the work of the canonists particulary American, among whom Stephen J. Kelleher, who drafted the first project of these norms should be mentioned.

The norms were issued by the Council for International Church Affairs with the special approval of pope Paul VI, for a period of three vears in order that they might be tried out, and put in force on the 1st July 1970 .

They aim ,ad expeditiorem reddendum causarum de nullitate matrimonii cursum" and their publication for the United States was motivated "consideratis peculiaribus sui territorii necessitatibus". They abrogate the rules of the general law in force, however in matters that are not raised by the norms, the rules of the Canon Law Code are to be obeyed.

The changes introduced by the norms are serious and many.

Te Holy See allows women to perform the office of a notary (n. 1). It allows a single judge to decide in certain cases of matrimonial affairs (nn. 3 and 23). It gives to advocates a number of prerogatives enabling them to take part in the lawsuit as equal partners of the defender of the bond (nn. 4, 8, 10, 11, 13, 14, 15, 17, 18, 19, 20, 23). It abolishes the restrictions of the Canon Law Code, which did not allow the persons who were the immediate and delibarate cause of the nullity of marriage to challenge the nullity of their marriage (n. 8). It shortens the terms of the trials (nn. 6, 8, 11, 13, 19, 20, 23), extends the rights of the promoter of justice in challenging the Vinvalid marriages (n. 9). It allows the promoter of justice under certain circumstances, when the nullity of marriage is to be declared on the basis of physical or psychic impotence, to consult only one expert who need not always examine the patient in person but his opinion may be based sovely on the gathered material.

The norms also establish two new titles for competence of the tribunals in matrimonial affairs namely the title of the residency and the title on which the Tribunal is better able to judge the case than any other Tribunal (n. 7).

During the course of the trial the judge may add not only an additional basis or bases for nullity (n. 11) but also the petitioner may request that the case be transferred from the competent tribunal to another competent tribunal (n. 12). The ruls concerning the office of a notary in the trial (n. 5) and the obligation of the examination of the experts have been simplified (n. 17).

An important novelty is the introduction into the norms of matrimonial trial of the concept of the prevailing weight of such evidence as is sufficient to declare the nullity of marriage (n. 21).

Another novelty is a new ordering of the matters related to the possible lack of validity of the acts of the trial: it is to be based on new principles. There is also an estimated enumeration of the cases in which the lack of validity of the sentence cannot be removed ( $n$. 22).

The second instance has been thoroughly reformed as the defender of the bond in the first instance may, under some circumstances be exempted from the diuty of appeal by Bishops' Conference (n. 23).

These norms as a whale are a major step forward in the development of procedure regulations concerning pronouncing of the nullity of marriages and shall certainly influence the general church legislation in this field.

Kraków, czérwiec 1971 r. 